\title{
The financial feasibility of compressed biomethane gas application in Thailand
}

\author{
Pennapa Tonrangklang ${ }^{1 *}\left(\mathbb{D}\right.$, Apichit Therdyothin ${ }^{1}$ and Itthichai Preechawuttipong ${ }^{2}$
}

\begin{abstract}
Background: Biomethane is a clean fuel upgraded from biogas. It has similar properties to natural gas vehicle (NGV) and can be used as a substitute for fossil fuels in the transportation and industrial sectors. Currently, biomethane is not in widespread use as alternative energy because it depends on local biogas production. However, there are few replacement alternatives and the commercial system is only on a small scale. Therefore, the overall aim of this paper is to study the financial feasibility of local biogas aggregation for producing biomethane on various scales. The results of the study are expected to aid the decision-making of investors and governments in promoting the use of renewable and sustainable sources of energy.

Methods: Primary and secondary data are used in this research for descriptive and quantitative analysis, while net present value, internal rate of return, payback period, and cost per unit represent the financial instruments. The location and distance methods applied are Google Maps and Power Bl software programs, based on biogas upgrading by water scrubbing.

Results: The results indicate that 10 potential biomethane production areas exist in Thailand, with a total biogas production capacity of $6,000 \mathrm{~m}^{3} /$ day or more under gas pipeline conditions not exceeding $50 \mathrm{~km}$. Compressed biomethane gas plants with a capacity of less than 6 tons/day should be funded by the government at $30 \%$ of the total investment for a payback period of 5-6 years. Plants producing more than 6 tons/day provide a good return on investment even without government funding.

Conclusions: While this study focuses solely on areas of Thailand, it is the researcher's position that the integration of residual biogas plants provides greater benefit than flare, particularly in remote areas. The model proposed in this study can serve as a prototype for developing countries such as Malaysia, the Philippines, Latin America, etc. Furthermore, it can be used in developed countries committed to reducing greenhouse gas emissions in accordance with the Paris Agreement.
\end{abstract}

Keywords: Biogas, Biomethane, Compressed biomethane gas, Water scrubbing, Financial feasibility

*Correspondence: pennapa.t@cmu.ac.th

1 Energy Management Technology Program, School of Energy,

Environment and Materials, King Mongkut's University of Technology

Thonburi, 126 Pracha Uthit Rd., Bang Mod, Thung Khru, Bangkok 10140, Thailand

Full list of author information is available at the end of the article

\section{Background}

Located in the center of Southeast Asia, Thailand covers approximately $513,120 \mathrm{~km}^{2}$ and has a total population of around 66.5 million [1]. Thailand's energy consumption in 2019 was 85,708 ktoe. Commercial energy consumption represented $84.2 \%$ of the total energy consumption with renewable energy representing 9.9\% (solar, hydropower, wind, and municipal solid waste) and traditional renewable energy 5.9\% (organic waste materials and industrial waste such as wood, coal, chaff, and agricultural substrate original author(s) and the source, provide a link to the Creative Commons licence, and indicate if changes were made. The images or other third party material in this article are included in the article's Creative Commons licence, unless indicated otherwise in a credit line to the material. If material is not included in the article's Creative Commons licence and your intended use is not permitted by statutory regulation or exceeds the permitted use, you will need to obtain permission directly from the copyright holder. To view a copy of this licence, visit http://creativecommons.org/licenses/by/4.0/. The Creative Commons Public Domain Dedication waiver (http://creativeco mmons.org/publicdomain/zero/1.0/) applies to the data made available in this article, unless otherwise stated in a credit line to the data. 
residue, etc.). However, petroleum products were responsible for the greatest proportion of energy consumption at $49.10 \%$ of the total, followed by electricity $20.25 \%$, alternative and renewable energy 9.95\%, coal/lignite products $8.30 \%$, natural gas $6.50 \%$, and traditional renewable energy $5.90 \%$ [2]. Agriculture is the main economic activity in the area, predominantly consisting of livestock farms involving cattle, pigs, chickens, etc., and cassava and sugarcane fields, which are primary economic crops and support the industrial sector. However, wastewater and waste are involved in most agricultural activities. As renewable energy, biogas is a sustainable alternative to fossil fuels, fuel oil, liquefied petroleum gas, electricity, etc., although it sometimes needs to be emitted into the atmosphere. Therefore, the quality of biogas should be improved to produce biomethane for vehicles and is one option for maximizing the use of agricultural waste. Since the agricultural sector mainly involves livestock farming, wastewater is drained into public rivers. Once sufficient research has been carried out on producing biogas by anaerobic digestion, it can be used to replace electricity and LPG. Currently, biogas can be upgraded into compressed biomethane gas for use in vehicles. It helps to reduce the use of fossil energy and the emission of greenhouse gases (methane) into the atmosphere.

In the past 2-3 years, there has been an increase in natural gas vehicle (NGV) users in Thailand due to high global oil prices. Therefore, the government has implemented a policy to encourage cars, public vehicles, and trucks to switch to natural gas by fixing the NGV gas price.

The Thai government has recently introduced the concept of biogas purification to produce biomethane as an option for replacing petroleum in areas far away from a natural gas pipeline, such as the north, northeast (south area), and south (west area), since the supply and transportation of NGV to these areas is difficult and expensive. The supply of energy is limited in these areas with the transportation costs based on the distance from the mother station or natural gas pipeline [3]. Consequently, through its Energy Policy and Planning Office, the government is promoting biomethane research to provide a solution to this problem by developing alternative energy using biogas purification for producing compressed biomethane gas (CBG). CBG is the only renewable energy source with the potential to replace LPG and $\mathrm{NGV}$, as well as the only form of alternative energy in Thailand that can replace fuel oil for vehicles. Biomethane gas is biogas which undergoes quality upgrading by removing $\mathrm{CO}_{2}, \mathrm{H}_{2} \mathrm{~S}$, and moisture [4] using technologies such as water scrubbing, pressure swing adsorption, and membrane separation to meet the vehicle fuel specifications. CBG is a form of clean energy and compared to diesel, benzene, fossil fuels, and liquefied petroleum gas, can reduce $\mathrm{CO}_{2}$ emissions by $78 \%$ [5], 90\% [6], 30-70\% [6], and $125 \%$ [7], respectively.

However, to replace NGV for use in vehicles, biomethane gas must be stored at high pressure (up to 200 bar) [8], because if stored below $200 \mathrm{bar}$, the storage tank must be larger, making it difficult to transport, and thus known as CBG. Biomethane gas and CBG have similar properties: they are lighter than air, experience no accumulation when leakage occurs, and only flammable at between 5 and $15 \%$ by volume at $650{ }^{\circ} \mathrm{C}$. However, they have different methane content, with biomethane containing more than $80 \%$ methane by volume. Biomethane purity standards vary according to country. For example, the Netherlands requires at least $85 \%$, Switzerland $96 \%$, and Sweden $97 \%$ of $\mathrm{CH}_{4}$ content in the injected biomethane [9]. The biomethane standard in Thailand is set according to the requirements of the Department of Energy Business and must have the same properties as NGV. According to government research, methane for engines should be $83-89 \%$ methane by volume [10]. Therefore, it can be directly used as an alternative to NGV. Moreover, in Thailand, the calorific value of biomethane gas for use in cars must be between 37 and $42 \mathrm{MJ} / \mathrm{Nm}^{3}$ [11].

Biogas plants are scattered throughout Thailand, although the country still lacks the necessary integration and cooperation to make the most of biogas benefits. Some biogas plants are located a considerable distance away from natural gas pipelines while other areas have many biogas plants with the potential to establish a compressed biomethane gas station for local transportation.

Therefore, the purpose of this study is to assess the biogas potential for biomethane production and financial feasibility of CBG through commercial analysis.

\section{Methods}

\section{Study area}

This study focuses on the financial feasibility of biomethane production in Thailand, divided into three main processes: (1) the review and evaluation of biogas and biomethane composition; (2) assessing the financial feasibility of biomethane production based on water scrubbing technology, consisting of technical costs analysis, system construction and maintenance costs, and energy and financial indicators; and (3) guidelines for applying the results of the study to target groups, as shown in Fig. 1.

During the biomethane production process, biogas is transported through pipelines to improve the quality to meet the required standards for increasing methane content. Water scrubbing involves the separation of $\mathrm{CO}_{2}$ and $\mathrm{H}_{2} \mathrm{~S}$ through a physical process, whereby the biogas is compressed into the bottom of the scrubber tank, with 


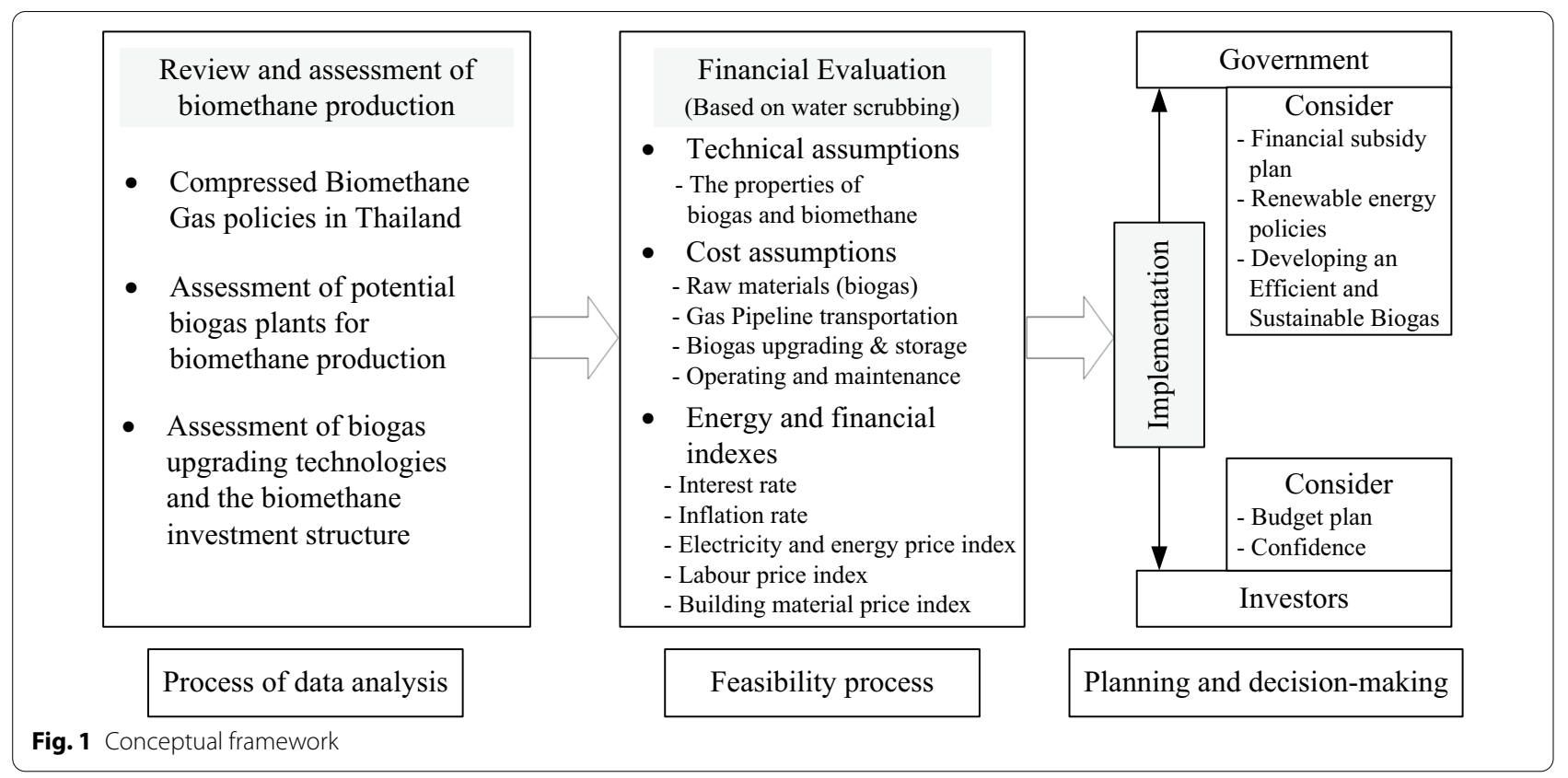

the media traps $\mathrm{H}_{2} \mathrm{~S}$ and water sprayed down from above. The carbon dioxide then comes into contact with the water and dissolves. The $\mathrm{CO}_{2}$ is subsequently discharged from the stripper tank and the water recirculated back into the system. During the production process, a small amount of biomethane is released with the water, but this will be looped back into the system. This method will result in high methane content, low cost, and can be used for vehicles or in the industrial sector (Fig. 2).

\section{Data analysis \\ Compressed biomethane gas policies in Thailand}

The Ministry of Energy is promoting the use of CBG to replace NGV under the Alternative Energy Development Plan (AEDP2015 and AEDP2018).

The proposed AEDP2015 aims to develop CBG as an alternative fuel in rural areas far from natural gas pipelines with a target to increase the proportion of energy usage by producing CBG from biogas to meet $5 \%$ of

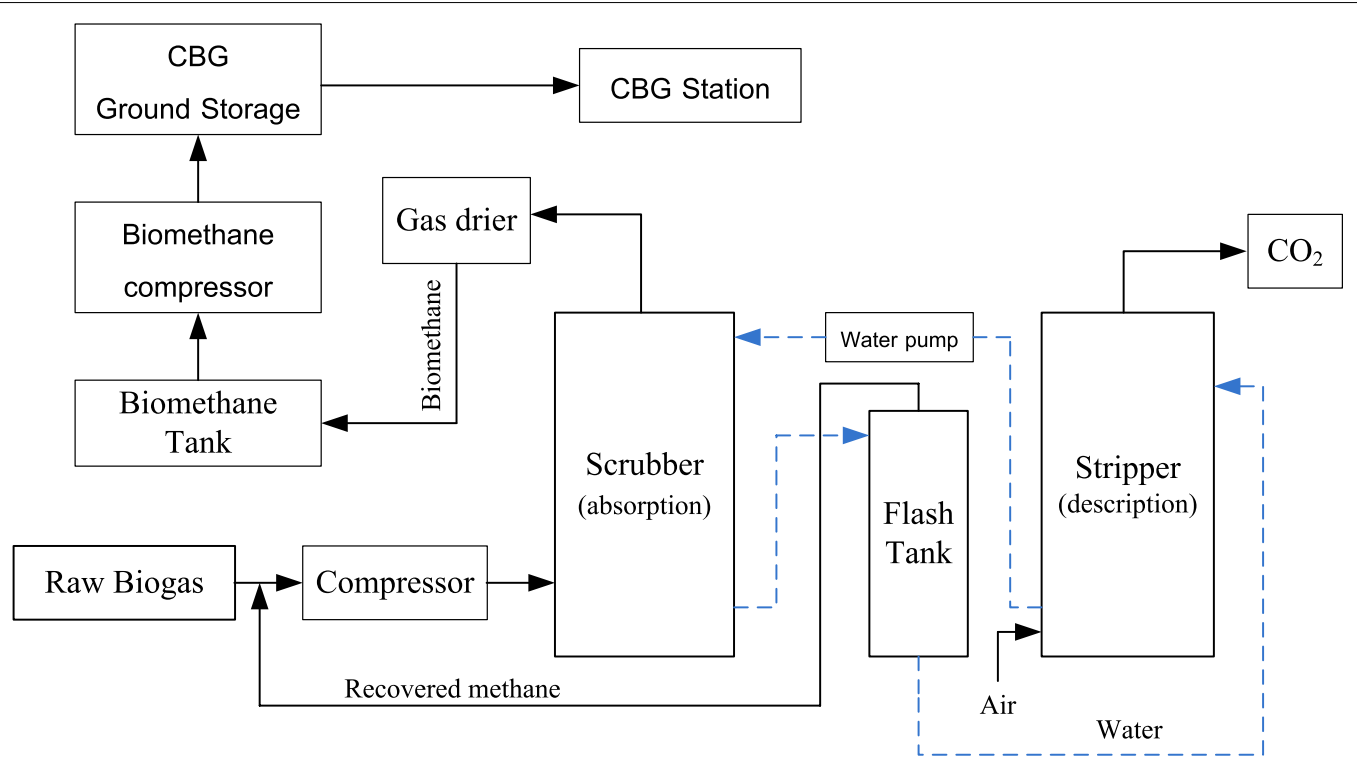

Fig. 2 Compressed biomethane gas process based on water scrubbing 
NGV demand with 4800 tons per day, or about 2000 ktoe by 2036 [12]. In accordance with AEDP2015, the Department of Alternative Energy Development and Efficiency, Ministry of Energy aims to develop renewable energy through compressed methane by upgrading technologies to replace LPG and natural gas for vehicles (NGV), while supporting owners of plants who already have a biogas system and sufficient biogas production capacity to produce CBG of no less than 3 tons/ day. The level of support on offer for the construction and installation of biogas upgrading and CBG systems is up to $15,000,000$ baht per plant for owners of large livestock farms and seven potential industrial groups: cassava starch, food and beverages, palm oil, whiskey and beer, rubber, paper, and ethanol. Such plants must currently be under construction, already operating a biogas system producing excess biogas from electricity/heat energy or experiencing problems in connecting to the electrical grid. Although they may have a biogas production capacity of no less than $6000 \mathrm{~m}^{3} /$ day, plants must have the potential to produce no less than 3 tons/ day of CBG. The total production of CBG from all project participants should be no less than 5000 tons/year. The government is supporting targeted areas more than $50 \mathrm{~km}$ away from natural gas pipelines. These include northern, central, southern, and northeastern areas and those with problems connecting to the electrical grid (feeder line). The direct subsidy from the government is $20-30 \%$ of the investment cost for biogas upgrading and CBG systems, as shown in Table 1.

Thailand is revising AEDP2018 (2018-2037) by adding the use of biomethane gas for heating purposes. This means that the characteristics of the developed biogas are comparable to those of NGV or liquefied natural gas (LNG). The target user group is the industrial sector, with the aim of replacing LNG as fuel in the production process, but the substitution is still 2023 ktoe (biomethane equivalent 4800 tons/day) [14]. The government plans to continue promoting the use of CBG. In addition, since biogas is the main raw material for producing CBG, government policies promote its production and use from wastewater and industrial waste. Government subsidies are used to support the cost of investment for owners of biogas production systems to support biogas pathways such as heating, electricity, and biomethane in the future.

On August 27, 2018, the Department of Energy Business, Ministry of Energy in Thailand announced the characteristics and quality standards of biomethane for vehicles, stating that the methane content should be more than 65\% [15]. However, although the characteristics and quality of biomethane may not be in accordance with the requirements, traders must report the relevant details to obtain prior approval from the Director-General.

\section{Assessment of potential biogas plants for producing biomethane}

Thailand currently has 1788 biogas plants from three main waste sources: 351 industrial factories, 1336 ranchlands, and 101 communities produce approximately 1405.58 million $\mathrm{m}^{3} /$ year of organic waste [16]. According to Wongsapai, Thailand has been promoting the installation of biogas systems since 1995 under the Energy Conservation Fund, Energy Policy and Planning Office (EPPO) [17]. The Thai government began promoting the use of biogas in its first swine farms, subsidizing approximately $33 \%$ of the total investment for design, construction, and consulting fees, with the owner contributing the remaining $67 \%$. Aggarangsi conducted a study on the development of biogas technology in Thailand's livestock farms, revealing that three main sectors in the country operate biogas systems: animal husbandry, the food industry, and community enterprises. These have the potential to produce more than 1 million $\mathrm{m}^{3} /$ year of biogas, but only $36 \%$ of the total biogas can be used to replace fossil fuels [18].

Therefore, as previously mentioned, for maximum benefit, biogas should be used to produce biomethane gas to support sustainable energy in Thailand. Accordingly, the objective of this research is to identify areas with the potential to operate compressed biomethane gas stations to provide fuel for vehicles using the biogas system database of the Energy Policy and Planning Office. Only biogas plants larger than $2000 \mathrm{~m}^{3}$ should be considered since these have the potential to produce sufficient biomethane gas [19]. There are 348 such plants in Thailand: 88 located in the northeastern

Table 1 Investment support by the Thai government for compressed biomethane gas production [13]

\begin{tabular}{ll}
\hline Capacity CBG & Subsidy conditions \\
\hline $3000-5999 \mathrm{~kg} /$ day & $\begin{array}{l}\text { Less than or equal to } 30 \% \text { of the investment in biogas upgrading and compressed biomethane gas systems, but not exceeding } 9 \\
\text { million baht per project }\end{array}$ \\
$6000-11,999 \mathrm{~kg} /$ day & $\begin{array}{l}\text { Less than or equal to } 25 \% \text { of the investment in biogas upgrading and compressed biomethane gas systems, but not exceeding } \\
12 \text { million baht per project }\end{array}$ \\
$\begin{array}{ll}\text { Equal to or greater } \\
\text { than 12,000 kg/day }\end{array}$ & \begin{tabular}{l}
15 million baht per project \\
\hline
\end{tabular}
\end{tabular}




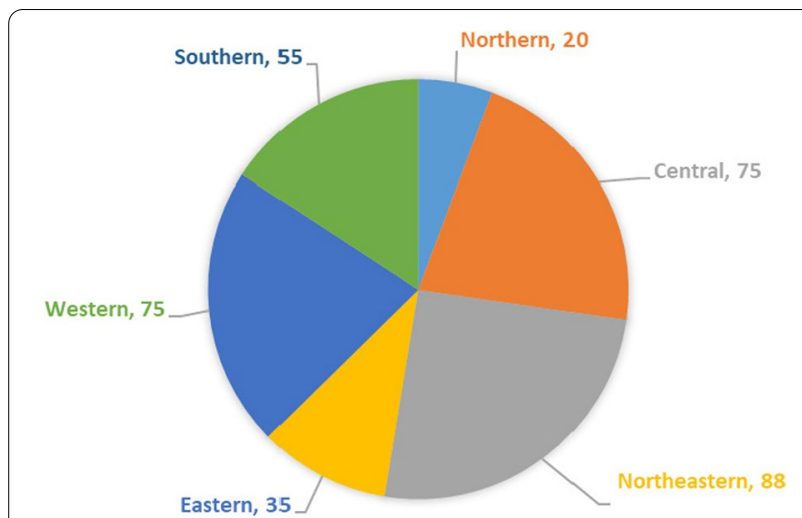

Fig. 3 Biogas plants in Thailand with a digester volume equal to or greater than $2000 \mathrm{~m}^{3}$ by region

region, 75 in each of the central and western regions, 55 in the southern region, 35 in the eastern region, and 20 in the northern region, as shown in Fig. 3.

The information for this research was collected from a total sample group of 156 plants using a survey questionnaire. The sample consisted of 81 plants in the industrial sector and 65 livestock farms, to establish the proportion of biogas produced for consumption and residual biogas utilization. The survey results show that the amount of biogas consumption equates to $51-80 \%$ of the total biogas produced by livestock farms and the industrial sector. Biogas can be used to replace three types of energy in the production process: electricity generated from the grid, fuel oil in a steam boiler, and cooking gas (LPG). Therefore, the amount of residual biogas utilization equates to approximately $20-50 \%$ of the total biogas produced. Biogas plants with digesters less than $10,000 \mathrm{~m}^{3}$ produce excess biogas equal to approximately $20 \%$ of the total biogas produced, while biogas digesters measuring 10,001-15,000 $\mathrm{m}^{3}$ utilize residual biogas equal to approximately $30 \%$ of the total biogas produced. Moreover, biogas digesters measuring $15,001-20,000 \mathrm{~m}^{3}$ utilized residual biogas equal to approximately $40 \%$ of the total biogas produced, while those larger than $20,000 \mathrm{~m}^{3}$ utilized residual biogas equal to approximately $50 \%$ of the total biogas produced. The eastern region has the most residual biogas at $77 \%$ of the potential biogas produced. This region has a natural gas pipeline, as a result, power plants and industrial sectors use natural gas, which is cheaper. Therefore, the amount of residual biogas required for a gas combustion system, by the southern, central, and northeastern regions is 41,40 , and $39 \%$, respectively (Fig. 4). Accordingly, these figures are used to calculate the capacity required for biomethane production.

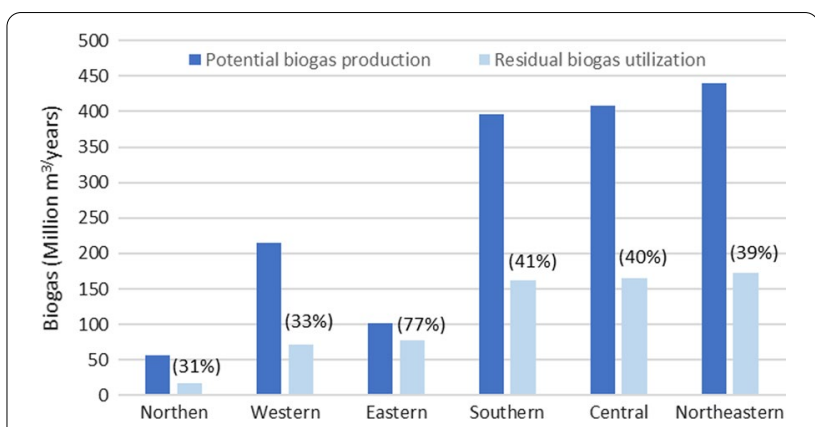

Fig. 4 Comparison between potential biogas production and residual biogas utilization by region

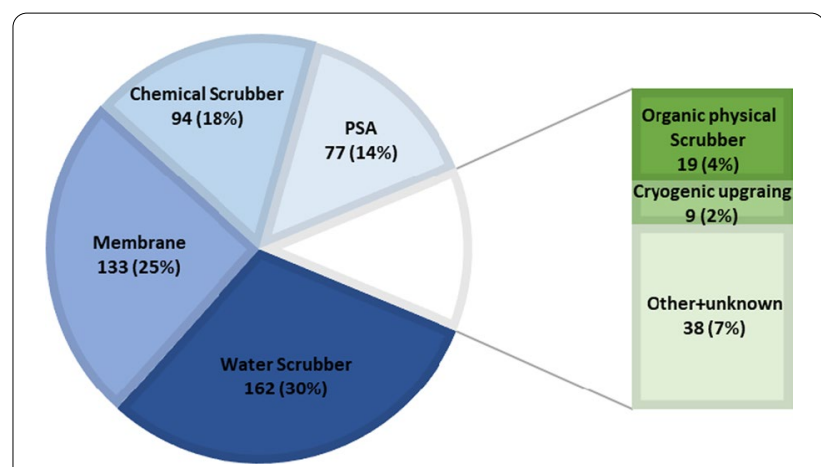

Fig. 5 The number of biogas upgrading technologies being used around the world in 2017. Adapted from IEA [20]

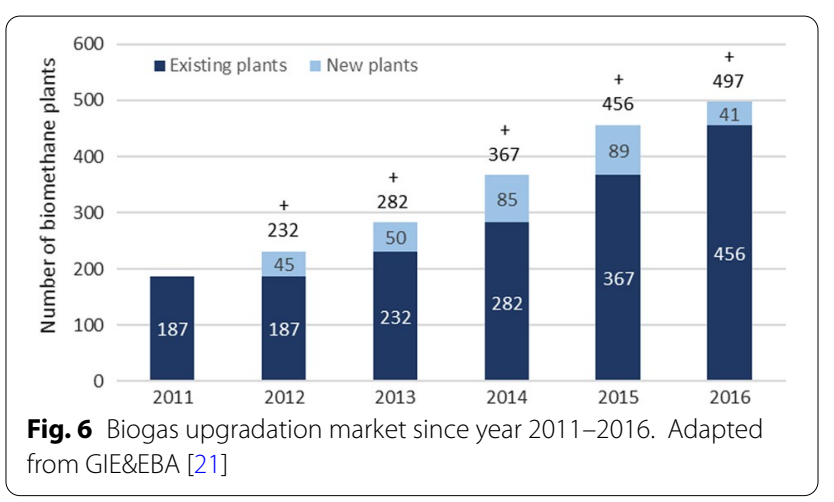

\section{Investment structure and conditions for financial feasibility}

According to a review of the biomethane technology in 2016, water scrubbing (WS) had the highest market share at $30 \%$, followed by membranes which were used in approximately $25 \%$ of all available biogas upgrading technologies in 2017 (Fig. 5) [20]. The use of biomethane has been growing steadily around the world since 2011, with more than 497 biogas upgrading plants operating in 2016 compared to 187 plants in 2011 (Fig. 6). Therefore, 
this study focuses on the cost of biomethane technology based on water scrubbing.

Water scrubbing (WS) requires low capital investment and operating expenditure without the need for highly skilled operators (Table 2). The biomethane gas production expenditure can be divided into biogas cost, upgrading capital cost, upgrading operations and maintenance cost, capital cost of compressing equipment, compressing operations, and maintenance cost. The Energy Research and Development Institute at Chiang Mai University studied a local gas grid project and submitted it to the Energy Policy and Planning Office. The results show that $1 \mathrm{~m}^{3}$ of biogas (at $\mathrm{CH}_{4} 55 \%$ by volume) converts to $\mathrm{CBG}$ production of $0.45 \mathrm{~kg}$, including the cost of the biogas transportation pipeline at approximately 702,777 baht $/ \mathrm{km}$. The transportation pipeline cost consists of exploring the areas, digging, piping the HDPE system, installing various equipment, testing, dismantling and repairing road surfaces, warning signs for gas pipes, and stop/shut-off/drain valves. The cost of materials/equipment and labor costs are included.

The researcher reviewed the appropriate biomethane cost-based pricing guidelines to determine the cost structure for biomethane production. The price structure is divided into two parts, separated according to the production process, namely the material cost (biogas purchase), the biogas pipeline cost, and the biogas upgrading cost (biomethane production process). The product unit was set in the form of baht per kilogram. The scope of analysis is shown in Fig. 7.

The cost-based pricing approach is applied in this study, according to the "Biomethane Promotion Strategic Plan Project for Commercial Energy Use" prepared by the Energy Research Institute, Chulalongkorn University. A financial model is proposed whereby the suitable internal financial rate of return (FIRR) for the project is determined by the purchase price of biomethane. This reflects an investment return similar to that of other businesses

Table 2 Properties of biogas upgrading technologies

\begin{tabular}{|c|c|c|c|c|}
\hline Parameters & WS & AS & PSA & MS \\
\hline $\mathrm{CH}_{4}$ purity $[22]$ & $>97 \%$ & $>95 \%$ & $95-98 \%$ & $>96 \%$ \\
\hline $\mathrm{CH}_{4}$ losses $[22]$ & $>2 \%$ & $<0.1 \%$ & $<0.1 \%$ & 0 \\
\hline Power demand ( $\mathrm{kWh} / \mathrm{m}^{3}$ raw gas) [23] & 0.25 & 0.42 & 0.25 & 0.5 \\
\hline \multicolumn{5}{|l|}{ Capital expenditures (million baht) [24] } \\
\hline 3 ton-CBG/day $\left(250 \mathrm{~m}^{3}-\mathrm{BG} / \mathrm{h}\right)$ & 41.5 & 62.9 & 44.1 & 40.7 \\
\hline 6 ton-CBG/day $\left(500 \mathrm{~m}^{3}-\mathrm{BG} / \mathrm{h}\right)$ & 59.7 & 82.2 & 63.7 & 60.1 \\
\hline 12 ton-CBG/day (1000 m³-BG/h) & 85.5 & 107.4 & 92.0 & 88.6 \\
\hline 24 ton-CBG/day) $\left(2000\right.$ m³-BG/h) $^{3}$ & 123.3 & 140.3 & 133.0 & 130.6 \\
\hline \multicolumn{5}{|l|}{ Operating Expenditures (million baht) [24] } \\
\hline 3 ton-CBG/day (250 m³-BG/h) & 5.1 & 6.9 & 9.5 & 5.4 \\
\hline 6 ton-CBG/day $\left(500 \mathrm{~m}^{3}-\mathrm{BG} / \mathrm{h}\right)$ & 8.2 & 11.9 & 17.4 & 9.4 \\
\hline 12 ton-CBG/day (1000 m³-BG/h) & 13.3 & 20.6 & 32.1 & 16.1 \\
\hline 24 ton-CBG/day) $\left(2000 \mathrm{~m}^{3}-\mathrm{BG} / \mathrm{h}\right)$ & 21.6 & 36.5 & 59.0 & 27.7 \\
\hline Volume system [25] & Moderate & Low & Moderate & Lower \\
\hline Site area [25] & Moderate & Low & Moderate & Low \\
\hline Skills of operator [25] & Moderate & Moderate & Moderate & High \\
\hline
\end{tabular}

WS water scrubbing, $A S$ amine-absorption method, $P S A$ pressure swing adsorption, $M S$ membrane separation, $B G$ biogas

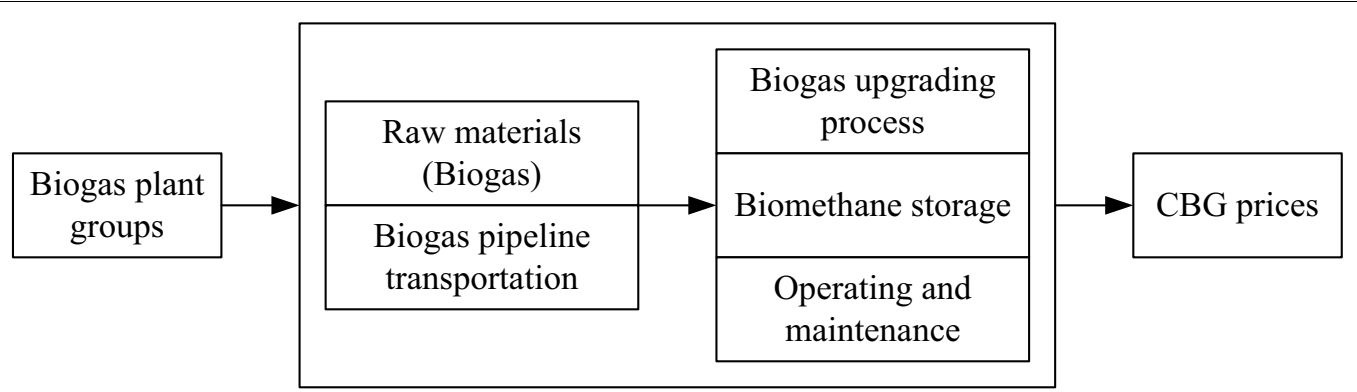

Fig. 7 Scope of CBG costs analysis 
at the same risk level. The financial model used to determine the purchase price of biomethane consists of a future cash flow valuation throughout the project life (this study analyzes the project life at 15 years) involving inflows and outflows. The cash flow must be high enough to motivate investors to participate in the development of the biomethane system but not so high as to place a burden on the government in the long term.

To conduct a spatial assessment of suitable areas for producing biomethane in Thailand, the researcher surveyed biogas plants across the country using questionnaires with stratified sampling. Biogas plants sufficiently near a biomethane gas distribution station for transferring biogas by pipeline were selected, determined by a transportation distance of no more than $50 \mathrm{~km}$. The CBG production capacity of $3,6,12$, and 24 tons/day was compared between the case of no government subsidy, $20 \%$, and $30 \%$ subsidies, respectively. Thailand has one currently active commercial CBG plant capable of replacing NGV. This plant purchases biogas at $2 \mathrm{THB} / \mathrm{kg}_{\text {biogas }}$ and $\mathrm{CBG}$ at $15.68 \mathrm{THB} / \mathrm{kg}_{\mathrm{CBG}}$. The total capital cost and operation/maintenance of CBG at a capacity of 3, 6, 12, and 24 tons/day equates to $46.6,67.9,98.8$, and 144.9 MTHB, respectively (the cost details are shown in Fig. 8).

This study compares the equivalent heating value between CBG and NGV for vehicles of $43.46 \mathrm{MJ} / \mathrm{kg}$ (95\% mol of methane). Investment feasibility analysis is applied to the compressed biomethane gas stations to identify the financial indicators, namely: net present value (NPV), financial internal rate of return (FIRR), payback period (PP), and cost per unit according to the conditions presented in Table 3.

The discount rate used to calculate the net present value and payback period is $6.89 \%$ since the average loan interest rate of the Bank of Thailand returns to MLR in 5 years (2015-2019). The salvage value is the anticipated amount received after 15 years. It accounts for $10 \%$ of the

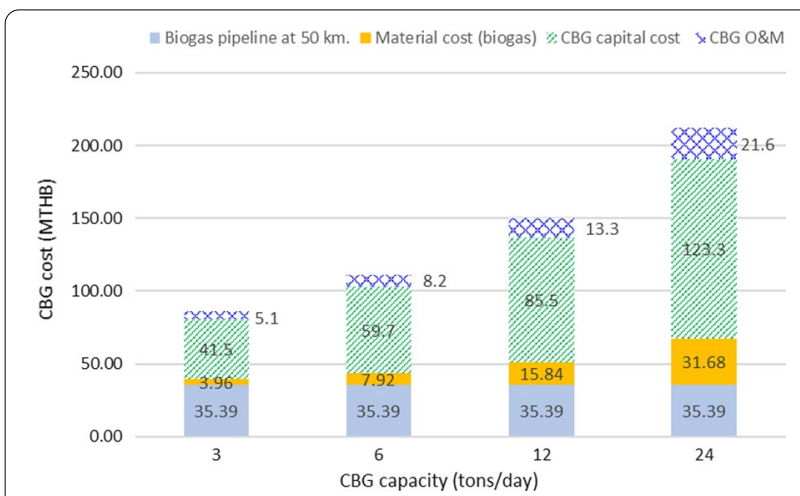

Fig. 8 The structure of compressed biomethane gas cost (excluded cost of biogas system)
Table 3 Conditions for the financial feasibility of a compressed biomethane gas plants

\begin{tabular}{ll}
\hline Factors & Details \\
\hline Discount rate (\%) & 6.89 \\
Biogas pipeline transportation cost (baht/km) [12] & 702,777 \\
Biogas price (baht/m3)@CH4 55\% by Vol. [12] & 2.00 \\
CBG price (baht/kg) [12] & 15.68 \\
Production period per year (day) [12] & 330 \\
Life of technology (year) [12] & 15 \\
Salvage value (\%) [12] & 10 \\
\hline
\end{tabular}

capital investment which is used by the government to estimate the value of a local gas grid project.

\section{Results}

\section{Potential biogas plants}

The network of pipelines in Thailand currently stretches $4255 \mathrm{~km}$ from onshore to offshore [26]. Pipelines run through the central, western, and eastern areas, meaning that most of the transportation sector chooses to use natural gas as fuel, especially since the cost of natural gas is lower than biomethane gas. According to the Ministry of Energy's biomethane production promotion plan, areas far away from natural gas pipelines must bear the burden of higher fuel costs, while other parts of the country do not. Therefore, this research analyzes only these areas and the transportation of biogas from plants to CBG stations no further than $50 \mathrm{~km}$ away. Based on the research principles of the PTT in 2017, the cost of transporting NGV for more than $50 \mathrm{~km}$ is not worth the investment. There is also the problem of using the highway as the main route for transporting biogas from the pipeline to the compressed biomethane gas plant. The location and distance from the pipeline for potential biogas production plants can be obtained from Google Maps and the Power BI program. Information on biogas systems in Thailand has been obtained for this study from the database of the Ministry of Energy and questionnaire surveys. All the data were entered into an Excel file consisting of the name of biogas plant, location, size of the digester, source waste, capacity, amount of biogas produced, and residual biogas. The information was then sorted according to the amount of biogas produced and residual biogas from highest to lowest. The data were subsequently imported into the Power BI program, with the location of the biogas system indicated according to the relevant conditions. The program compared locations in the area according to the amount of biogas produced using different colors. Only the locations of biogas plants 
with residual biogas and a biogas system size greater than $2000 \mathrm{~m}^{3}$ were selected. The coordinates were then entered into Google Maps for comparison with the location of the natural gas pipeline in Thailand. The GPS system was used to locate the main highway and measure the distance from the natural gas pipeline.

The biogas plant groups in this study consist of biogas systems located within a radius of $50 \mathrm{~km}$ from each other, which are restricted by their inability to apply for a power purchasing agreement, under the assumption that they will not be able to operate at full capacity and there is a large amount of biogas to flare. Therefore, these biogas systems have the potential to be upgraded to biomethane. The following ten groups were identified:

Group A has two biogas plants with a pipeline transportation distance of $20 \mathrm{~km}$.

Group B has three biogas plants with a pipeline transportation distance of $24 \mathrm{~km}$.

Group $\mathrm{C}$ has four biogas plants with a pipeline transportation distance of $35 \mathrm{~km}$.

Group D has five biogas plants with a pipeline transportation distance of $20 \mathrm{~km}$.

Group E has five biogas plants with a pipeline transportation distance of $20 \mathrm{~km}$.

Group F has four biogas plants with a pipeline transportation distance of $37 \mathrm{~km}$.

Group $\mathrm{G}$ has three biogas plants with a pipeline transportation distance of $7 \mathrm{~km}$.

Group $\mathrm{H}$ has three biogas plants with a pipeline transportation distance of $10 \mathrm{~km}$.

Group I has two biogas plants with a pipeline transportation distance of $33 \mathrm{~km}$.

Group J has three biogas plants with a pipeline transportation distance of $33 \mathrm{~km}$.

Groups C, I, and D have a CBG production capacity of 3 tons/day with the remaining biogas from the utilization equating to $8,324,250 \mathrm{~m}^{3} /$ year. Groups $\mathrm{G}$ and J have a CBG capacity of 6 tons/day with the remaining biogas from the utilization equating to $10,758,000 \mathrm{~m}^{3} /$ year. Groups A, B, and E have a CBG production capacity of 12 tons/day with the remaining biogas from the utilization equating to $28,795,800 \mathrm{~m}^{3}$ /year. Groups $\mathrm{H}$ and F have a CBG production capacity of 24 tons/day with the remaining biogas from the utilization equating to $34,412,400 \mathrm{~m}^{3} /$ year, as presented in Table 4 .

The results of this study reveal that despite Thailand having a large biogas surplus (approximately 82,290,450 $\mathrm{m}^{3}$ /year), the country is still unable to utilize this biogas to its full potential. Thailand should therefore use as much of this biogas as possible for renewable energy.
Table 4 Potential of biogas plant groups to biomethane production

\begin{tabular}{lcc}
\hline $\begin{array}{l}\text { Group of biogas } \\
\text { plants }\end{array}$ & $\begin{array}{l}\text { Quantity of biogas } \\
\text { ( } \mathbf{m}^{\mathbf{3}} \text { /year) }\end{array}$ & $\begin{array}{l}\text { CBG capacity } \\
\text { (tons/year) }\end{array}$ \\
\hline A & $7,048,800$ & 3172 \\
B & $9,570,000$ & 4307 \\
C & $2,244,000$ & 1010 \\
D & $3,606,240$ & 1623 \\
E & $12,177,000$ & 5480 \\
F & $17,820,000$ & 8019 \\
G & $5,049,000$ & 2272 \\
H & $16,592,400$ & 7467 \\
I & $2,474,010$ & 1113 \\
J & $5,709,000$ & 2569 \\
Total & $82,290,450$ & 37,031 \\
\hline
\end{tabular}

\section{Financial feasibility analysis}

The financial investment analysis is divided into three cases: (1) no subsidy from the government; (2) a $20 \%$ subsidy of the total investment; and (3) a 30\% subsidy of the total investment. The biogas systems are grouped according to a CBG production capacity of $3,6,12$, and 24 tons/ day under the condition that the distance for biogas transportation by pipeline does not exceed $50 \mathrm{~km}$.

In the case of no subsidy from the government, the financial internal rate of return (FIRR) from a CBG production capacity of $3,6,12$, and 24 tons/day is $7.97,10.12$, 25.13 , and $28.44 \%$, respectively. Production at 3 tons/ day has the longest payback period of 9.28 years with a unit cost of $14.65 \mathrm{baht} / \mathrm{kg}_{\mathrm{CBG}}$, while a production capacity of 24 tons/day has the shortest payback period of 3.58 years with a unit cost of $12.26 \mathrm{baht} / \mathrm{kg}_{\mathrm{CBG}}$. Therefore, CBG plants with a production capacity of 12 tons/day or more demonstrate the greatest investment potential because the FIRR is higher than the market rate $(12 \%)$. In the case of a $20 \%$ subsidy of the total investment from the government, the FIRR from a CBG production capacity of $3,6,12$, and 24 tons/day is $11.64,14.09,31.83$, and $35.83 \%$, respectively. A production capacity of 3 tons/day has the longest payback period of 7.53 years with a unit cost of $14.02 \mathrm{baht} / \mathrm{kg}_{\mathrm{CBG}}$, while a capacity of 24 tons/day has the shortest payback period of 2.68 years with a unit cost of $11.99 \mathrm{baht} / \mathrm{kg}_{\mathrm{CBG}}$. Therefore, CBG plants with a production capacity of 6 tons/day or more demonstrate the greatest investment potential because the FIRR is higher than the market rate. In the case of a $30 \%$ subsidy of the total investment from the government, the FIRR at a CBG production capacity of $3,6,12$, and 24 tons/day is $14.08,16.76,36.52$, and $41.04 \%$, respectively. A production capacity of 3 tons/day has the longest payback period of 6.28 years with a unit cost of $13.70 \mathrm{baht} / \mathrm{kg}_{\mathrm{CBG}}$, 
while a capacity of 24 tons/day has the shortest payback period of 2.36 years with a unit cost of $11.86 \mathrm{baht} / \mathrm{kg}_{\mathrm{CBG}}$. Therefore, all CBG plants exhibit investment potential, as shown in Table 5.

Accordingly, in the case of no subsidy from the government at a maximum production capacity of 24 tons/ day, the costs will be lowest when CGB is produced at a $16.31 \%$ capacity ( 3 tons/day). With a $20 \%$ subsidy at the maximum capacity of 24 tons/day, the costs will be lower with a production capacity of $14.48 \%$ (3 tons/day), while a $30 \%$ subsidy at the maximum capacity of 24 tons/day at the lowest production capacity of $13.43 \%$ ( 3 tons/day) is the most cost-effective. The results show that the amount of biogas entering the system and the transportation distance from the pipeline affect the financial viability of the project. Increased production capacity at the CBG plants results in a lower price per unit (Figs. 9 and 10). However, biomethane has the potential to be cost-effective in terms of performance while also providing a renewable energy option for businesses. In particular, large-scale biogas plants producing more than 12 tons/day are likely to be more competitive in the market, while small CBG plants producing less than 12 tons/day are less cost-effective because the production costs will still be higher than for other fuels.

\section{Discussion}

The findings of this study reveal that Thailand does not make full use of biogas and its potential to produce biomethane, which is consistent with Aggarangsi et al. [18].

Table 5 Investment feasibility analysis of compressed biomethane gas plants

\begin{tabular}{ccccc}
\hline Indicators & $\begin{array}{l}\text { FIRR } \\
\text { (\%) }\end{array}$ & $\begin{array}{c}\text { NPV } \\
\text { (MTHB) }\end{array}$ & $\begin{array}{l}\text { PP } \\
\text { (year) }\end{array}$ & $\begin{array}{l}\text { Cost per } \\
\text { unit (THB/ } \\
\text { kg) }\end{array}$ \\
\hline \multicolumn{5}{c}{ Case 1: No price subsidy from government } \\
3 tons/day & 7.97 & 5.35 & 9.28 & 14.65 \\
6 tons/day & 10.12 & 20.32 & 8.38 & 14.22 \\
12 tons/day & 25.13 & 169.27 & 4.15 & 12.45 \\
24 tons/day & 28.44 & 267.43 & 3.58 & 12.26 \\
Case 2: Subsidy from the government at 20\% of the total investment \\
3 tons/day & 11.64 & 19.69 & 7.53 & 14.02 \\
6 tons/day & 14.09 & 38.07 & 6.29 & 13.67 \\
12 tons/day & 31.83 & 191.90 & 2.99 & 12.15 \\
24 tons/day & 35.83 & 297.07 & 2.68 & 11.99 \\
Case 3: Subsidy from the government at 30\% of the total investment \\
3 tons/day & 14.08 & 26.86 & 6.28 & 13.70 \\
6 tons/day & 16.76 & 46.94 & 5.61 & 13.39 \\
12 tons/day & 36.52 & 203.22 & 2.63 & 12.01 \\
24 tons/day & 41.04 & 311.90 & 2.36 & 11.86 \\
\hline
\end{tabular}

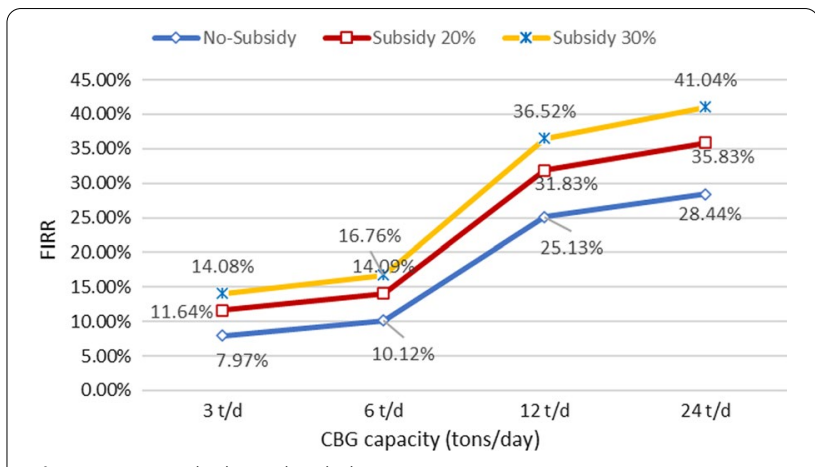

Fig. 9 FIRR with the subsidy by CBG capacity

The government's financial support will help improve the FIRR of the project, which is consistent with Wongsapai et al. [17]. This study reveals the financial feasibility of each scale of CBG production. Finally, appropriate planning policies and recommendations can be derived from the findings of this study.

CBG is an alternative clean renewable fuel for consumers. There are three main reasons why the government should provide investment support: (1) it is the only renewable energy with similar properties to natural gas; (2) it can replace NGV; and (3) it can be transported via the natural gas pipeline or employed in various devices that use natural gas as fuel.

Therefore, financial support from the government is required to support CBG production for three reasons: (1) it would encourage operators to invest in service stations located in remote areas; (2) it can reduce the risk factors involved in natural gas supply, especially since natural gas reserves in the Gulf of Thailand have decreased. Therefore, Thailand needs to import natural gas and LNG from Myanmar which is expensive [27], affecting the development of NGV usage in Thailand; and (3) it can reduce the use of fossil fuels which cause air pollution, thereby improving the environment.

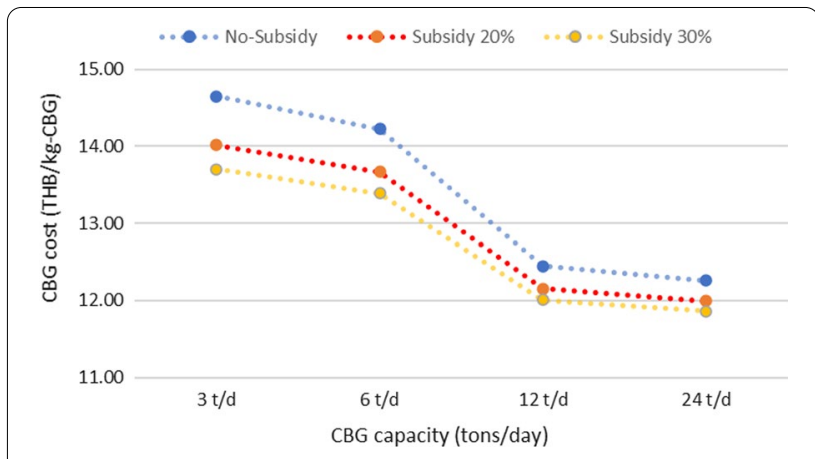

Fig. 10 Cost per unit with the subsidy by CBG capacity 
In summary, the model used in this study to promote CBG distribution stations in Thailand can be divided into three phases: the first phase is short-term promotion (1-2 years), involving large investors (to produce CBG at a rate of more than 12 tons/day) or financial readiness and a technology-respected person who has the confidence to invest. Thus, this group should promote the use of water scrubbing technology due to its cost-effectiveness and the establishment of stations in the area as potential prototypes for other entrepreneurs. This group should be supported by a government subsidy of no more than $20 \%$ of the total investment as a model to attract small entrepreneurs, with investment support measures, tax measures, low-interest loans, etc. The second phase involves middle-term promotion (3-5 years), representing the start of technology growth to enable entrepreneurs to quickly gain market share. Therefore, if the government wants biomethane to be used as renewable energy in remote areas, it should be subsidizing all CBG plants; a CGB plant subsidy of $30 \%$ with a production capacity of less than 6 tons/day, and less than 20\% for CBG plants with a production capacity of more than 12 tons/day. The third phase involves long-term promotion (6 years onward), representing the beginning of market saturation. During this period, if the government wants to seriously support the continuous construction of biomethane gas stations to replace fossil fuels, it needs to provide a relatively high purchase price subsidy. In addition, the government should offer similar assistance as that suggested for the first phase such as investment support measures, tax measures, low-interest loans, etc. (Fig. 11).

However, to attract private investors, the financial rate of return needs to be higher than the market rate. The government should set both rates at an appropriate level. In addition, the government should consider the benefits to people using the energy to ensure the service fee is fair to both investors and customers.

In addition, the government should implement policies for renewable energy to expand the use of biomethane in industry as well as private and public transportation, etc., because not only is biomethane a renewable energy source, it also helps to reduce greenhouse gas emissions. Moreover, the development of biomethane plants would support the policy of the UNFCCC, reinforcing Thailand's commitment to reducing greenhouse gases by $20-25 \%$ by 2030 [28]. This policy aims to drastically reduce fossil fuel consumption while increasing the use of clean energy through environmentally friendly processes, thereby supporting the common goal of many countries around the world, namely, to reduce global warming.

A review of the Local Gas Grid document [29] reveals that pipeline transport over $50 \mathrm{~km}$ is not worth the financial investment and installation of a biomethane pipeline in remote areas far away from the natural gas pipeline can be carried out by the community. Therefore, the integration of biogas plants within a radius of no more than $50 \mathrm{~km}$ to produce biomethane is an alternative for driving production in remote areas, giving communities the opportunity to produce their own energy and use clean affordable fuel.

The model in this study will benefit both developing and developed countries, as detailed below.

European Union (EU): Europe aims to reduce carbon and develop biomethane by 2020-2050. European countries are biogas-driven and utilize organic waste sources and the agricultural sector to produce biogas. Biogas can be upgraded to biomethane for various applications

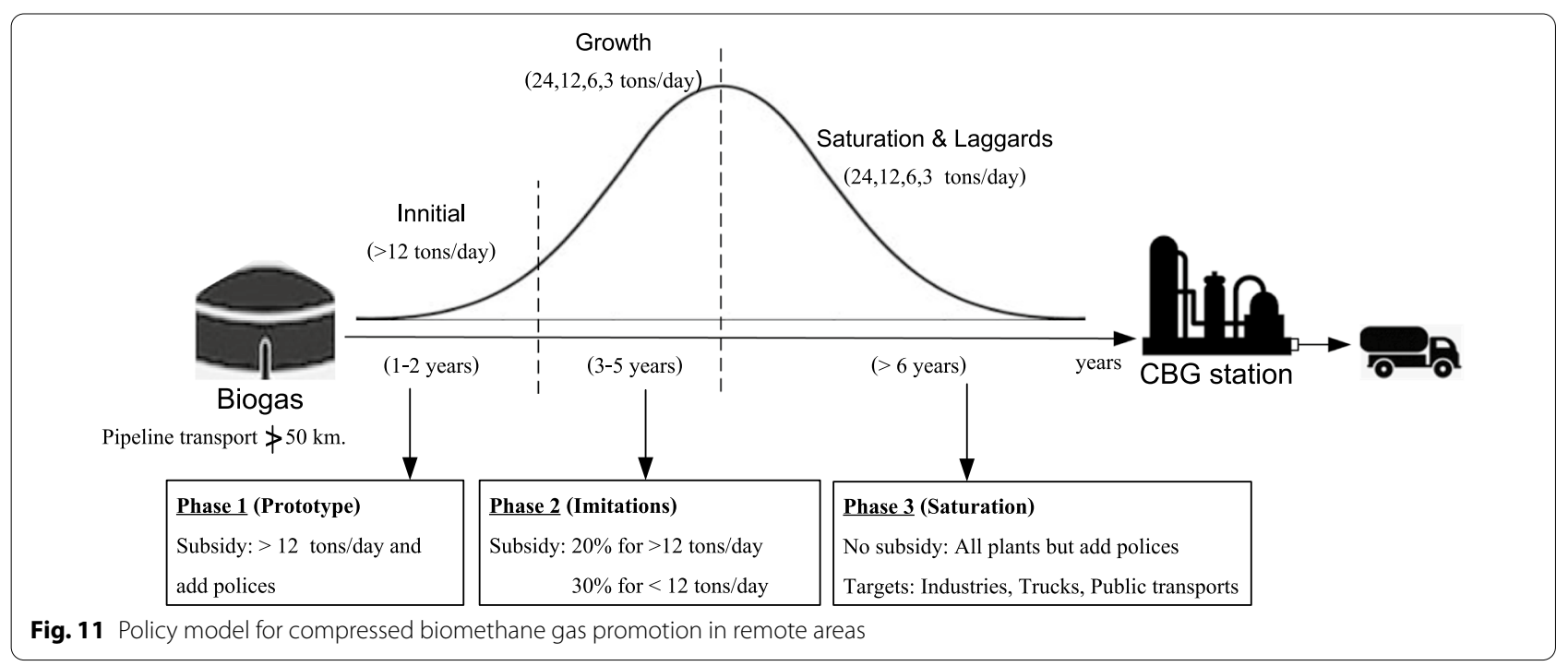


(transportation, chemical production, heat, etc.). Currently, European policies are pushing the sector to increase its sustainability and reduce biogas production costs [30]. The EU residues of maize, wheat, barley, and rapeseed contribute $78 \%$ to the EU agricultural biogas potential [31].

Latin American countries: Biogas technology is widely applied in landfill gas technology in developing countries. Biogas is used for cooking, lighting, or as a vehicle fuel, but mainly in urban gas. The amount of biogas produced in Latin America is approximately 217 million cubic meters per year [32]. However, if this group of countries employs this research model to further upgrade biogas to biomethane, more clean fuels can be used domestically, especially in remote areas.

Chile is poor in fossil fuel resources. Therefore, it imports most of its energy from abroad (68\%) while the remaining 32\% comes from domestic sources (mostly from hydroelectric power and coal). Chile imports $83 \%$ of its petroleum and there is a risk of an energy shortage in the future. In 2019, the Chilean government developed short, medium, and long-term public energy policies to increase investment in clean fuels for remote areas by 2050 [33]. The country is aiming for a 30\% reduction in greenhouse gas emissions by 2030 [34]. Therefore, this research is informative for supporting decision-making on clean fuel investment (biomethane) in remote areas.

Malaysia: Currently, more than $80 \%$ of Malaysia's solid waste is disposed of at landfills. As a result, Malaysia urgently needs to move toward sustainable solid waste management, and the recycling of organic waste is crucial. Specifically, anaerobic fermentation to produce biogas will lead to energy and environmental sustainability in the domestic market [35]. Therefore, this research extends the analysis of the financial worthiness regarding biogas upgrades. It is also a biomethane for investment in clean fuel.

Republic of the Philippines: The Philippines is an archipelago and the islands are among the most affected by worsening climate change. The Philippines has been mandated to use biofuels through the Biofuels Act 2006. Thus, foreign companies are interested in bioenergy investment to help the Philippines develop more energy sources [36]. Since the biomethane model in this study can be installed on an island, the problem of transportation between the islands can be resolved, helping investors and the government to develop clean fuel in all island areas.

\section{Conclusion}

Thailand has 10 potential areas for establishing CBG plants. If the government does not support investment in biogas plants with a production capacity of less than
6 tons/day, payback periods of $8-9$ years may be unattractive to investors seeking a quick return. In this group, the government should support investment with a 30\% subsidy of the total cost at a payback period of 5-6 years. The government may not need to provide any subsidies to biogas plants with a production capacity of more than 6 tons/day, because the returns are worthwhile. Moreover, if there is no support for this group, the creation of a commercial prototype may not be possible. Therefore, the government should provide a subsidy of less than $20 \%$ to motivate this group. Subsidies from the government are important for ensuring investor confidence in renewable energy, providing opportunities for biogas operators all over the country who are interested in investing to produce biogas at full capacity. Currently, CBG is the only renewable energy with similar properties to NGV for reducing the natural gas supply. Thailand will then be encouraged to move toward energy sustainability.

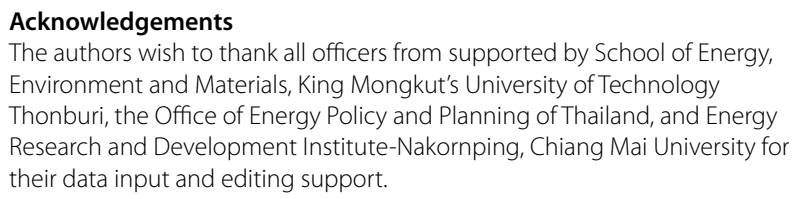

Authors' contributions

The authors have read and approved the final manuscript.

Funding

This research was kindly funded by School of Energy, Environment and Materials, King Mongkut's University of Technology Thonburi.

Availability of data and materials

Not applicable.

\section{Declarations}

Ethics approval and consent to participate

Not applicable.

Consent for publication

Not applicable.

Competing interests

The authors declare no competing interest.

\section{Author details}

${ }^{1}$ Energy Management Technology Program, School of Energy, Environment and Materials, King Mongkut's University of Technology Thonburi, 126 Pracha Uthit Rd., Bang Mod, Thung Khru, Bangkok 10140, Thailand. ²Department of Mechanical Engineering, Faculty of Engineering, Chiang Mai University, 239 Huay Kaew Rd., Muang District, Chiang Mai 50200, Thailand.

Received: 5 March 2021 Accepted: 11 February 2022

Published online: 18 February 2022

\section{References}

1. Population Reference Bureau. World Population Data Sheet. https://www. prb.org/2020-world-population-data-sheet/ (2021). Accessed 28 Feb 2021 
2. Department of Alternative Energy Development and Efficiency (2019) Energy balance of Thailand 6:1

3. Energy policy and planning office, Ministry of Energy (2013) Biogas and Compressed biomethane gas is the hope of renewable energy for Thailand. Energy Policy J 102:16-28

4. Puttapoun W, Moran JC, Aggarangsi P, Bunkham A (2015) Powering Shuttle kilns with compressed Biomethane gas for the Thai ceramic industry. Energy Sustain Dev 28:95-101. https://doi.org/10.1016/j.esd.2015.08.001

5. Madhusudhanan AK, Na X, Boies A, Cebon D (2020) Modelling and evaluation of a biomethane truck for transport performance and cost. Transp Res Part D 87:102530. https://doi.org/10.1016/j.trd.2020.102530

6. German Biogas Association. Biomethane: energy for the road. https:// www.biogas.org/edcom/webfvb.nsf/id/en-biomethane (2021). Accessed 13 Aug 2021

7. California Energy Commission. Biofuels: Biomethane. https://www. energy.ca.gov/programs-and-topics/programs/clean-transportationprogram/clean-transportation-funding-areas-2-1 (2021). Accessed 13 Aug 2021

8. Koonaphapdeelert S, Moran JC, Aggarangsi P, Bunkham A (2018) Low pressure biomethane gas adsorption by activated carbon. Energy Sustain Dev 43:196-202. https://doi.org/10.1016/j.esd.2018.01.010

9. Suwansri S, Moran JC, Aggarangsi P, Tippayawong N, Bunkham A, Rerkkriangkrai P (2014) A biomethane solution for domestic cooking in Thailand Energy Sustain Dev 23:68-77. https://doi.org/10.1016/j.esd.2014.08.003

10. Energy Research and Development Institute-Nakornping, Chiang Mai University. CMU-CBG. https://erdi.cmu.ac.th/wp-content/uploads/2020/ 12/CBG.pdf. Accessed 12 Feb 2020

11. Worasaen A, Pannucharoenwong N, Benjapiyaporn C, Jongpluempiti J, Vengsungnle P (2017) Suitable study of CBG fuel by considering in wobbe index from compressed bio-methane gas plant, Khon Kaen University, Thailand. Energy Procedia 138:278-281. https://doi.org/10.1016/j. egypro.2017.10.061

12. Energy Research and Development Institute, Chiang Mai University. Local gas grid project. Submitted to Energy policy and planning office, Ministry of Energy (2017).

13. Department of Alternative Energy Development and Efficiency, Ministry of Energy. Funding Guide Compressed Biomethane production (CBG) project. pp 1-9 (2016)

14. Department of Alternative Energy Development and Efficiency, Ministry of Energy. Alternative Energy Development Plan. https://www.dede.go. th/download/Plan_62/20201021_TIEB_AEDP2018.pdf (2018). Accessed 3 Dec 2019

15. Department of Energy Business, Announcement of the Department of Energy Business on Determines the properties and quality of biomethane for vehicles, http://elaw.doeb.go.th/document_doeb/TH/664_0001 pdf. Accessed 12 Feb 2020

16. Saengprajak A, Katcharoen A, Chockua W, Piamdee J (2019) Prospective study of application the direct-biogas solid oxide fuel cell system to the biogas plant in Thailand. Energy Procedia 158:978-983. https://doi.org/ 10.1016/j.egypro.2019.01.239

17. Wongsapai W, Thiengburanathum P, Rerkkriengkrai P (2008) Biogas situation and development in Thai swine farm. Renew Energy Power Qual J 1:222-226. https://doi.org/10.24084/repqj06.269

18. Aggarangsi P, Tippayawong N, Moran JC, Rekkriangkrai P (2013) Overview of livestock biogas technology development and implementation in Thailand. Energy Sustain Dev 17:371-377. https://doi.org/10.1016/j.esd. 2013.03.004

19. Energy policy and planning office, Ministry of Energy. Alternative Energy Development Plan: AEDP2015. http://www.eppo.go.th (2015). Accessed 3 Dec 2019

20. IEA Bioenergy. Task 37: Country report summary. https://www.ieabioener gy.com/wp-content/uploads/2018/09/IEA-Bioer-T37CRS-2017_Final.pdf (2017). Accessed 14 Aug 2021

21. Gas Infrastructure Europe and the European Biogas Association. European Biomethane Map 2018. https://www.gie.eu/download/maps/2018/ GIE BIO 2018_AO 1189x841.pdf (2018). Accessed 14 Feb 2020

22. Hjuler K, Aryal N. Review of Biogas Upgrading, Future Gas project report. Dansk Gasteknisk Center (2017).

23. Adnan Al, Ong MY, Nomanbhay S, Chew KW, Show PL (2019) Technologies for biogas upgrading to biomethane: a review. Bioeng Bioeng 6:92. https://doi.org/10.3390/bioengineering6040092
24. Department of Alternative Energy Development and Efficiency, Ministry of Energy. Potential and target of biogas to produce CBG. https://www. dede.go.th/download/files/Focus\%20group_CBG\%20part.pdf (2015). Accessed 16 Jan 2020

25. Department of Industrial. Practice guides for design, production, quality control and the use of biogas for industrial sector, pp. 1-43 (2010)

26. PTT Public Company Limited. Natural gas pipelines system. https://www. pttplc.com/th/Products/Ourbusinessbypttplc/Gasunit/Transmissionand distributionpipeline.aspx (2018). Accessed 10 Mar 2020

27. Energy policy and planning office, Ministry of Energy. Energy Statistics of Thailand 2021. https://drive.google.com/file/d/1SCKwm9psfL6VZN 4NDCodqJLfa3s8hKo0/view (2021). Accessed 15 Aug 2021

28. Office of Natural Resources and Environmental Policy and Planning. Thailand third biennial update report. https://climate.onep.go.th/wp-conte nt/uploads/2021/01/BUR3_Thailand_251220-.pdf (2020). Accessed 29 Dec 2020

29. Koonaphapdeelert S, Aggarangsi P, Moran JC (2020) Biomethane to local gas grids. Green Energy Technol. https://doi.org/10.1007/ 978-981-13-8307-6

30. Brémond U, Bertrandias A, Steyer JP, Bernet N, Carrere H (2021) A vision of European biogas sector development towards 2030: Trends and challenges. J Clean Prod 287:125065. https://doi.org/10.1016/j.jclepro.2020. 125065

31. Yuan ZL, Gerbens-Leenes PW (2021) Biogas feedstock potentials and related water footprints from residues in China and the European Union. Sci Total Environ 793:148340. https://doi.org/10.1016/j.scitotenv.2021. 148340

32. Ni JQ, Naveau H, Nyns EJ (1993) Biogas: exploitation of a renewable energy in Latin America. Renew Energy 3:763-779. https://doi.org/10. 1016/0960-1481(93)90084-T

33. Arze LF, Poblete A. Renewable energy law and regulation in Chile. https:// cms.law/en/int/expert-guides/cms-expert-guide-to-renewable-energy/ chile (2019). Accessed 8 Nov 2021

34. Bertram R. Good news from Chile. https://energytransition.org/2021/05/ good-news-from-chile/ (2021). Accessed 8 Nov 2021

35. Yong ZJ, Bashir MJK, Hassan MS (2021) Biogas and biofertilizer production from organic fraction municipal solid waste for sustainable circular economy and environmental protection in Malaysia. Sci Total Environ 776:145961. https://doi.org/10.1016/j.scitotenv.2021.145961

36. Marquez GPB, Santiañez WJE, Trono GC, Montaño MNE, Araki H, Takeuchi H, Hasegawa T (2014) Seaweed biomass of the Philippines: sustainable feedstock for biogas production. Renew Sust Energ Rev 38:1056-1068. https://doi.org/10.1016/j.rser.2014.07.056

\section{Publisher's Note}

Springer Nature remains neutral with regard to jurisdictional claims in published maps and institutional affiliations.

Ready to submit your research? Choose BMC and benefit from:

- fast, convenient online submission

- thorough peer review by experienced researchers in your field

- rapid publication on acceptance

- support for research data, including large and complex data types

- gold Open Access which fosters wider collaboration and increased citations

- maximum visibility for your research: over 100M website views per year

At BMC, research is always in progress.

Learn more biomedcentral.com/submissions 